\title{
The European Union's Promotion of Minority Protection in Serbia - Effectiveness of the EU in External Democratization in Sandžak
}

\author{
Henriette Heimbach*
}

\begin{abstract}
Since the Copenhagen Council in 1993, potential EU candidate countries such as Serbia need to fulfil the political criteria of respect for and protection of minorities. National minorities in Serbia such as the Bosniaks are not yet fully respected which can give rise to political instability. This paper brings into focus the EU's leverage in the democratization process of Serbia. How effective is the EU in promoting minority protection in Serbia? So far, positive signals are sent out by the formation of a Ministry for Human and Minority Rights and by National Minority Councils. Regarding minority protection, EU effectiveness primarily relies on political conditionality and norm convergence. While the membership perspective presents a strong incentive for Serbia to comply, norm convergence is hampered by the vague definition of the minority criterion.
\end{abstract}

Keywords: External democracy promotion by the EU, minority protection, Serbia Externe Demokratieförderung der EU, Schutz nationaler Minderheiten, Serbien

\section{Introduction}

$\mathrm{T}$ The Copenhagen criterion of respect for and protection of minorities presents a milestone in the protection of minorities that had been convened between nationstates. After the disastrous successor wars in Yugoslavia in the 1990s, the European Union (EU) clearly conceived the security dimension of the Copenhagen criterion. With regard to its immediate neighbourhood, the EU judges the settling of interand intra-state conflicts as indispensable for countries such as Serbia that are willing to join the EU.

Serbia's democratic transition started in 2000 with the election defeat of President Slobodan Milošević and his extradition to the International Criminal Tribunal for the former Yugoslavia (ICTY) in The Hague, 2001. During the European Council Summit in Feira 2000 and in Thessaloniki 2003, the EU confirmed the European perspective of Serbia, once it meets the enlargement criteria including minority protection. Serbia took part in the Stabilization and Association Process (SAP) leading to the Stabilization and Association Agreement (SAA) and the Interim Trade Agreement in 2008. On 22 December 2009 Serbia handed over its membership application, which was transferred to the Commission by the European Council on 25 October 2010. With Boris Tadić as President elected in 2004 and re-elected in 2008, Serbia has a pro-Western leader that strongly advocates EU integration. During this rapprochement, the EU used its leverage to enforce democratic change. A good example for the EU's influence is the arrest of former war criminal Ratko Mladić in May 2011. His extradition to the ICTY presents one of the main conditions that have to be fulfilled in order to reach candidate status and improves significantly Serbia's membership perspective. With regard to the promotion of minority protection in Serbia, political conditionality and

\footnotetext{
Henriette Heimbach holds a Master degree in European Politics of the Institut des Etudes Politiques in Strasbourg and one in European Studies of the European University Viadrina in Frankfurt/Oder. This article has successfully undergone a double-blind peer-review process.
}

norm convergence play an important role. How effective is the EU's promotion of minority protection in Serbia?

This paper argues that the EU has been primarily effective in the adoption of a legal framework on minority protection. Political conditionality based on the membership perspective successfully caused compliance with EU demands for minority protection. However, implementation went only slowly. The monitoring by the EU progress reports did not take place continuously and lacks clear benchmarks. Here, socialization through norm convergence is hindered due to the loose definition of national minority by the EU. As the EU's leverage mainly focuses on the national level, it has been less successful in the Sandžak region. After presenting the main theoretical concepts underlying this study, the shortcomings in the EU's national minority concept will be discussed followed by the case study on the EU's effectiveness in the promotion of minority protection in Serbia and in particular in Sandžak.

Serbia forms a very multi-ethnic state that faces difficulties in the accommodation and protection of its national minorities. Here, the focus is on the Bosniaks, Muslim Slavs that live in the Sandžak region and present the second largest national minority in Serbia after Hungarians. The Sandžak region is not only marked by a high degree of unemployment, poverty and an underdeveloped infrastructure, but also by deep divisions in the Muslim community accompanied by violations within their community. Due to a continuing regional dispute and the neglect by the Serbian government and the international community, Sandžak could become the next powder keg in the region.

\section{EU Political Conditionality and Convergence}

Since the accessions in 2004 and 2007, EU enlargement is strongly correlated to the external democratization of potential applicant and candidate states. The unprecedented entry of 10 post-communist countries into the EU was accompanied by 
a strong political will in the EU for democratization of these countries and even more important the settlement of potential intra- and interstate conflicts. ${ }^{1}$ International relations as well as transition theory have dealt with external democratization as research object (see Burnell 2010, Grävingholt et al. 2009, Kubicek 2003, Kelley 2004, Merkel 2010, Grimm 2009). By definition, external democratization relates to an external democratic actor that engages in the implementation of democracy in another environment than its own (Beichelt 2010, p. 448). Looking at transition processes, it is often impossible to neatly identify the influence of external actors. Democratic change is induced by a complex interplay of internal and external factors as well as a favourable political opportunity structure (see Tarrow 1998). So far, research on Serbia's external democratization process is still rare and empirical studies are needed in order to analyse the process and the actors involved in democracy promotion (for an exception see Wichmann 2007).

In general, different instruments and processes how democracy is brought about are discussed amongst academics ranging from control, coercion and conditionality to diffusion, demonstration effect, incorporation, contagion, convergence, consent, adaptation, socialization or learning. Here, political conditionality was singled out as prevalent instrument used by the European Commission as main actor in the EU enlargement process (Schimmelfennig 2008, p. 918). According to Kubicek, these different terms can be reduced to four categories as their explanatory power often overlap with each other: contagion, control, convergence and conditionality (Kubicek 2003, p. 4-7). Thus, adaption or incorporation, for example, are here regarded as subcategories to convergence. With regard to democracy promotion, control can be excluded as approach to the EU enlargement policy, given that the EU does not force a candidate country militarily to conduct reforms. Regarding contagion, Kubicek argues: "It is a "supply-side theory" [...]. It neglects the agency and intent of international actors" (Kubicek 2003 , p. 5). The concept of contagion assumes that democracy is passively brought about by the very existence of the EU as role model that does not act. When taking the actorness of EU and Serbian leaders into account, convergence and conditionality remain the only explanatory concepts for the EU's democracy promotion in candidate countries.

\subsection{Norm Convergence}

Convergence is here understood as an alignment of potential candidate countries with EU expectations and norms in an asymmetric process. As Kubicek formulates, this can be reached through a rationalist calculation by domestic elites in order to receive the benefits resulting from compliance with EU demands (Kubicek 2003, p. 6). As the promotion of minority protection seems to be first and foremost the promotion of a specific international norm, this paper takes into consideration convergence by norm adaption. In this sense, convergence

1 Post-communist countries that joined the EU in 2004 and 2007 are Poland, Czech Republic, Slovakia, Slovenia, Hungary, Romania, Bulgaria, Estonia, Lithuania and Latvia. means the adaption to democratic norms through socialization and incorporation. ${ }^{2}$ This means that decision makers act accordingly to what they think is appropriate. Thus, it changes actors' belief (Kelley 2004, p. 428). The more protection of minorities is acknowledged as common good and argued with in political life, the more politicians will be judged based on the respect of this norm and adjust their behaviour along these expectations (logic of appropriateness). In theory, norm adaption can take place through different channels such as intensive dialogue between the EU and Serbia in this case, causing spill-over effects from the rhetorical level to real action. Moreover, transnational networks bringing together civil society from within the EU and Serbian non-governmental actors can promote democratic norms. Norm adaption is also successful if the respective norm minority protection resonates in the Serbian society and does not face opposing norms such as strong nationalism (Checkel 2001, p. 563). The receptivity for new norms is higher if society and politics are in transition as there is a window of opportunity for reform and new democratic actors.

\subsection{Political Conditionality}

Political conditionality plays a major role in the promotion of minority protection as earlier studies on the 2004 and 2007 enlargement have shown. Here, the prospect of membership has triggered reform regarding the integration of the Russianspeaking minorities, for example in Latvia and Estonia (Kelley 2004, p. 441-447). While convergence is based on a social constructivist perspective, conditionality refers to rational choice theory. Thus, political actors comply with EU demands on the basis of a cost/benefit calculation. Hereby, the prospect of membership delivers a strong incentive for compliance with EU conditions that are held against potential domestic costs (Schimmelfennig 2008, p. 920). Candidate countries comply as they expect an increase in economic and social welfare (logic of consequentialism). Political conditionality is two-fold: positive (rewards) and negative (sanctions, exclusion) conditionality induce compliance. However, conditionality is successful provided that rewards/carrots and sanctions/sticks are credible and the concerned country has no alternatives. Importantly, Vachudeva points to the costs of exclusion from membership, which can be marginalization, a lack of market access and of foreign investment, and difficulties to participate in the global economy (Vachudeva 2005, p. 65).

Studying the EU's promotion of minority protection in Serbia, the author combines social constructivism and rational choice theory. The EU membership perspective offers the framework for compliance in various policy fields while the intensified dialogue on different levels between Serbia and the EU causes a socialization effect. Following Judith Kelley's reasoning, the membership incentive plays a crucial role for the democratization effort of Serbia while socialization and norm convergence rather guide EU-Serbia relations (Kelley 2004, p. 426). Taking this into account, two hypotheses

2 See also Kubicek 2003, p. 12: "As discussed above, convergence can be understood as
system conformity produced by the spread and acceptance of democratic norms." 
are formulated that were tested in the study based on the EU's progress reports and the assessments of international organizations on the ground:

i) The EU is effective if minority protection as a norm is a clear, coherent and consistent EU standard and does not contradict with concurring norms (social constructivism).

ii) The EU is effective in the promotion of minority protection, if the external incentives for democratic change such as the membership perspective are credible and exceed the cost of compliance (rational choice approach).

Beginning with the first hypothesis, the following chapter takes a closer look at the EU minority concept and the development of the Copenhagen criterion minority protection.

\section{EU National Minority Concept}

\subsection{History of the Minority Criterion}

The question of how to accommodate national minorities often emerges after wars and in transition periods. The subject of national minorities has always been an issue to international concern as it often straddles borders. Thus, after the Second World War in 1945 the settling of borders and the management of cross-border ethnic groups presented a crucial matter. During the Cold War from 1945 to 1989-91, the minority issue was only marginally discussed in the international community. After the collapse of the Soviet Union, former Soviet republics and satellite states became independent and claimed international recognition (Jackson-Preece 1998, p. 43). At the same time the countries of the then European Community feared conflicts and war between the new states in their immediate neighbourhood and aimed at regulating inter-state relations. At a European Council summit in Copenhagen in 1993 the EU governments agreed on criteria that set up certain conditions for candidate states for EU membership. Influenced by the Copenhagen document of the Commission on Security and Cooperation in Europe (CSCE) from 1990 and with the political will to settle ethnic conflicts before EU accession, the political criteria include the protection of minorities: "Membership requires that the candidate country has achieved stability of institutions guaranteeing democracy, human rights, the rule of law and respect for and protection of minorities." (Council of the European Communities 1993)

From then on, the EU accession of possible candidate countries was closely tied to the fulfilment of the minority protection criterion, which was new in the history of international relations. The protection of minorities in order to prevent ethnic hostilities became particularly important with regard to the Yugoslav successor wars in the 1990s. The Badinter Committee, set up for arbitration in former Yugoslavia, and the Pact on Stability in Europe in 1995 focused on the accommodation of national minorities. The Framework Convention for the Protection of National Minorities (FCNM) signed in 1995 and ratified by all Council of Europe (CoE) members, except France, Turkey, Andorra and Monaco, was a cornerstone to minority protection. ${ }^{3}$ Similarly, the constitution of a High Commissioner on National Minorities of the Organization for Security and Cooperation in Europe (OSCE) increased the significance that was attached to the protection of national minorities. The EU started to entrust the Council of Europe and OSCE with the assessment of minority protection and relies crucially on their evaluation of a candidate state's reform. Both usually have local offices in the respective country that engage in monitoring and assistance programs. As both institutions rearranged their focus on Human and Minority Rights in the 1990s, they acquired a strong expertise that the EU cannot provide (Skovgaard 2009, p. 9).

\subsection{Looseness of the Term National Minority}

Equal to all agreements is the loose term of national minority that is not clearly defined. The explanatory report to the FCNM even explains: "It should also be pointed out that the framework Convention contains no definition of the notion of "national minority". It was decided to adopt a pragmatic approach, [...]." (FCNM Explanatory report 1995, p. 13)

The answer to what ethnic group is to be treated as a national minority is context-specific and therefore also a political decision. Differences in the understanding of a national minority and its accommodation amongst the EU member states are overt if one takes into account that a few member states have not signed and ratified the FCNM. Consequently, it is not surprising that the Treaty of Amsterdam in 1997 contained all political and economic Copenhagen criteria except the criterion on minority protection. Authors such as Sasse, Hughes and De Witte speak of a double standard that is applied to candidate countries (Sasse and Hughes 2003, p. 11; Sasse 2008, p. 846-847; De Witte 2002, p. 139). De Witte points out the incongruence between the internal and the external use of the norm minority protection (De Witte 2002, p. 155). The Treaty of Lisbon in 2009 brought change as it gave the Charter of Fundamental Rights a legally binding character, except for Poland and the United Kingdom that opted out. The Charter sets out that any discrimination based on membership of a national minority shall be prohibited (Charter of Fundamental Rights Art. 2, § 1). However, an explicit protection of national minorities is not mentioned as demanded in the Copenhagen criteria for new member states, and the norm remains relatively in flux from a legal standpoint.

Looking at the practice of minority protection during the 2004 and 2007 enlargement process the EU seems to favour a consociationalist concept of minority accommodation based on regionalization and decentralization. This means that ethnic or other societal groups should be involved in power-sharing. While the concept is in favour of a high degree of cultural autonomy for each group based on the principle of subsidiarity, it tries to prevent any claims for territorial autonomy. The idea of consociationalism for national minorities aims first and foremost at the maintenance of security and stability

3 States that only signed but not yet ratified the FCNM are Belgium, Iceland, Luxembourg and Greece. 
and the prevention of conflicts in ethnically divided societies (Skovgaard 2009, p. 18).

The missing definition of the norm minority protection complicates the application of benchmarks and indicators to measure and enforce democratic reform. So far, regular reports and opinions of the European Commission and, in extreme cases, the abandonment of the accession process dispose means to put pressure on a candidate country. In the following, the case study on Serbia and in particular on the Bosniak minority presents the difficulties of measuring the effectiveness of the EU's promotion of minority protection in practice.

\section{The EU's Leverage on Minority Protection in Serbia}

In the last 10 years the EU established tight relations with Serbia and closely accompanied its democratization process. Besides norm convergence through increased face-to-face dialogue, the EU primarily used the membership incentive to induce democratic reform, also in the field of minority protection. Despite a certain enlargement fatigue after the last accession round, conditionality remains the concept of success for external democratization. The membership perspective is still credible as the EU regularly confirmed it (see the Feira, Zagreb and Thessaloniki European Councils); the more so as Serbia has no alternative and the costs of exclusion, such as lack of financial transfers and market access, are too high. However, the pre-accession process takes longer due to war legacies that need to be solved and the EU avoiding to set a clear timetable for accession. In trying to compensate the missing timetable, the EU delivers short-term incentives such as visa liberalization, which leads to a "creeping process towards membership" as Renner describes it (Renner 2009, p. 463). In the field of minority protection the EU mainly uses country progress reports as a monitoring tool to enforce democratic reform. In this regard it is crucial to distinguish between the EU's effectiveness against its own benchmarks and against the domestic background.

\subsection{The EU's Effectiveness against its Own Benchmarks}

As the EU progress reports cover a whole range of different topics from economic to juridical issues, minority protection forms only a small part of the overall assessment. Here, the EU focuses mainly on the Roma, Internally Displaced Persons (IDP) and refugees, while the Bosniak minority often plays a secondary role: in 2002 and 2003, Sandžak was referred to in the context of the need to solve crimes against Bosniaks; the 2004 and 2005 reports do not mention the Bosniak minority; since 2006 the Commission has increasingly named deficits in the Sandžak region and noted an aggravated situation related to inter- and intra-community tensions. Although the EU has not published or named any specific conditions for the protection of national minorities, three benchmarks can be singled out that recur in the progress reports of the European Commission and that where applied earlier in the enlargement rounds of 2004 and 2007:

1) Ratification and implementation of all relevant international conventions on minority protection

2) Non-discrimination of persons belonging to a national minority

3) Decentralization and regionalization

Taking up the first point, Serbia has relatively quickly signed all the relevant international conventions such as the FCNM, the European Charter on Regional and Minority Language and the European Convention on Human Rights and Fundamental Freedoms. Consequently, Serbia is a member state of the OSCE and the Council of Europe, which presents an unofficial prerequisite to EU membership and is well understood as such by Serbia. In this context Serbia also has to cooperate with the European Court of Human Rights of the Council of Europe. Nationally, it established a Ministry for Human and Minority Rights in 2000, National Minority Councils in 2002 and adopted the Federal Law on Human and Minority Rights in 2002. Especially after 2000, new democratic reformers such as Zoran Djindjić, Serbian prime minister until he was murdered in 2003, embraced democratic assistance by the EU and other international organizations to overcome domestic opposition. Thus, EU demands triggered reform in the field of minority protection and functioned as catalyst. Despite Serbia's adherence to the Council of Europe and OSCE, implementation of laws concerning minority protection is delayed and takes place only slowly. ${ }^{4}$ In Sandžak, the Bosniak National Council faced problems regarding its constitution as the Serbian Ministry for Human and Minority Rights surprisingly published a new Rulebook one day before its constitutive session on 7 July 2010 (YIHR 2010, p. 2). The EU progress reports closely followed up the implementation of the National Councils, albeit the choice of minority issues chosen in the reports appears rather random in general. With regard to the National Councils, continuous pressure from the EU successfully enforced their constitution.

Secondly, on a formal level the non-discrimination of persons belonging to an ethnic or other minority is reached, too. Nonetheless, discrimination of minorities in practice, in particular the Roma, Internally Displaced Persons (IDP) and refugees, persist, as Serb nationalism is still very strong and exclusive (Schimmelfennig 2008, p. 930). Regularly, the Commission criticized the slow implementation of minority protection laws and points to the fact that penalties for discriminatory practices in media and in the labour market are rarely imposed. But Sandžak is not explicitly mentioned in this context (EU progress report 2007, p. 14). With regard to the reconstitution of rights of Bosniaks by condemning war criminals, the Commission indicated shortcomings in its first progress reports. Nevertheless, this critique has not been taken up seriously in the following progress reports, although the problem persisted. Crimes committed during state terror in the 1990s include burning, robberies, murders, different kinds of

4 The Republic National Minority Council headed by the Prime minister me only a few times since its establishment. Equally, a law on the regulation and constitution of the National Minority Councils was only adopted in 2009 and first elections were held in June 2010 
institutional discrimination and brutal police actions (Sandžak Committee 2006, p. 4).

Thirdly, the EU favours the regionalization and decentralization as it corresponds much with its own constitution and enables minority representation. Exchange with EU and member state bodies on lower and regional levels through the EU twinning program or the Committee of the Regions increases adaption to European norms such as minority protection. Serbia is marked by a high degree of centralization. In this respect, some reforms have been made such as the Law on Local Self-Governance which was elaborated with the assistance of OSCE and CoE in 2001 and which introduced direct elections for the municipal assembly. In 2009 the autonomous region Vojvodina in the north of Serbia adopted a new statute granting it more competencies (Freedom House 2010, p. 458). ${ }^{5}$ In 2009 a Law on Regional Development enforced the reorganization of Serbian statistical districts in splitting Sandžak and the Bosniak community into two districts with Novi Pazar and Tutin belonging to the Raška region and Prijepolje, Sjenica, Priboj to the Zlatibor district. The division troubled the Bosniak community, as Sandžak is a historically evolved and culturally coherent region. Similarly, political representation of the Bosniak minority becomes more difficult in this way. Analysts have argued that Belgrade aims at avoiding an ethnically homogenous region that may encourage separatist movements (ICG 2005, p. 17).

Finally, the EU progress reports regularly mention that reforms advance significantly in the field of minority protection: "Good progress has been made in the protection of minorities" (European Commission 2010, p. 16). Against its own benchmarks, the EU has been rather successful when judging the overall situation of minorities in Serbia. In contradiction to this general assessment, the reports notice in detail an aggravating situation in Sandžak. Accordingly, the EU has been less effective with special regard to the Bosniak minority

\subsection{The EU's Effectiveness against the Domestic Background in Sandžak}

Regarding the protection of the Bosniak minority, there is still need for improvements despite some democratic progress. The Serbian state adopted the legislation on minority protection but lags behind in its implementation. In particular in Sandžak, the state did not enforce minority rights and has rather been absent. In order to measure democratic reform and the impact of the EU in Sandžak, three indicators are deployed:

\section{1) Legal protection and non-discrimination}

2) Political representation

3) Cultural autonomy (language use and free expression of culture and religion, education in and on the minority language)

Firstly, minority rights have been distinctively improved over the last ten years. Legal protection of ethnic minorities is guaranteed through the Serbian Constitution of 2006 that

5 Nevertheless, it took nearly a year until the national parliament agreed on the new statute in 2010. follows European standards as laid out in the FCNM. ${ }^{6}$ Still, Freedom House states in its report: "Municipal structures lack the capacity to fully enforce minority rights in Sandžak [...]" (Freedom House 2010, p. 466). The central government does not transfer enough financial means to local administrative structures, which is a major disadvantage for the realization of minority rights on the ground. Discrimination also continues in the field of education, employment and public services. Here, the Committee on the Elimination of Racial Discrimination working for the UN High Commissioner for Human Rights singled out a "structural discrimination" of Bosniaks (Committee on the Elimination of Racial Discrimination 2011, p. 5). For example, there is still a lack of Bosniaks in public administration, especially in police services. ${ }^{7}$

Secondly, the political representation of Bosniaks is realized by a development of a Bosniak and Serb party scene in Sandžak, including three Bosniak parties. ${ }^{8}$ An electoral reform in 2000 lifted the threshold of $5 \%$ for ethnic parties in parliamentary elections that had prevented them to join the national parliament. Since the elections in 2008 two Bosniak parties are taking part in the government and two Bosniak party leaders, Sulejman Ugljanin of the Party of Democratic Action (SDA) and Rasim Ljajić of the Sandžak Democratic Party (SDP), are holding the post of a Minister in Belgrade. ${ }^{9}$ Political decisionmaking in Sandžak has been strongly influenced by a longstanding dispute between Ugljanin, leader of the SDA, and his rival Ljajić, leader of the SDP, to the detriment of the Sandžak population. ${ }^{10}$ In 2009 reconciliation was reached through the mediation of Turkish Foreign Minister Ahmet Davutoglu visiting Belgrade and Novi Pazar (Helsinki Committee 2009, p. 395-398). Attempts to also resolve the dispute between the two religious leaders Mufti Muamer Zukorlić, head of the Islamic Community in Serbia, and Adem Zilkić, head of the Islamic Community of Serbia, failed. ${ }^{11}$ Problematically, the Serbian government does not address the conflicts prevailing in Sandžak. It seems to leave Sandžak on its own due to a lack of capacity and interest. The central government could benefit from a divided Bosniak community as it keeps separatist claims low. However, the Serbian government does not take any affirmative action to solve the conflict.

Thirdly, taking a glance at cultural autonomy, basic legalization concerning the use of language, free expression of culture

6 Yet, Article 20 of the new constitution called Restriction of Human and Minority Rights allows the retrenchment of Human and Minority Rights in the state of emergency and war (Szöke 2010, p. 201-202).

7 In Novi Pazar 50 per cent of the police staff is Serb, while the 80 per cent of the population are Bosniak (Helsinki Committee 2009, p. 379).

8 SDA, SDP and Sandžak's People Party (SNP) are ethnic parties that mainly collect Bosniak votes.

9 Rasim Ljajić (SDP) is Minister for Labour and Social Policy while Sulejman Ugljanin (SDA) is Minister without Portfolio.

10 Ljajić and Ugljanin have founded the first Bosniak party SDA in the beginning of the 1990s. Then, Ljajićleft the party in 1995 and created his own party, SDP. Apart from personal differences, he could not agree with Ugljanin engaging for a substantial autonomy of Sandžak both in Serbia and Montenegro. Ljajić rather favored the Serbian Sandžak's integration into Serbia through powersharing mechanisms (see also Bochsler 2010).

11 Divisions of the Muslim community evolved after the creation of the new Islamic Community of Serbia under Adem Zilkic in 2007 who "deposed" Zukorlić. Zilkić who receives support from the Serbian government and legitimates its claim for leadership through the recognition of the Riyaset (supreme council) of the Serbian Islamic Community in Belgrade. Zukorlic is traditionally tied to the Bosnian Riyaset in Sarajevo and was re-elected as chief of the Islamic Community in Serbia in 2008 (see also UN Special Rapporteur for Freedom of Religion and Belief 2009, p. 11). 
and religion, education in and on the minority language was adopted. Yet, there is a lack of capacity to transform the requirements for minority protection into reality. Some irregularities were noticed during the election of the Bosniak National Council in June 2010 when election material was not translated properly into Bosnian language (YIHR 2010, p. 2). With regard to education, Mufti Zukorlić founded the first and private university in Sandžak in Novi Pazar in 2002 and manages several Islamic secondary schools and an Islamic publishing house (ICG 2005, p. 24). Concerning religion, the 2006 Law on Churches and Religious Communities highlights the historic presence of Islam in Serbia. However, the existence of two Islamic communities does not correspond with registration procedures under the respective law. The Ministry of Religious Affairs, which is supposed to be impartial, has registered a second Islamic community of Serbia chaired by Adem Zilkić, which it favours. The division in two Islamic communities, as explained before, contributes greatly to the deteriorating situation in Sandžak. Especially, mufti Zukorlić increasingly engages in radical speech. Although he tried to internationalise the conflict and called on the EU that European Standards of minority protection are violated, the EU has not reacted to the smouldering conflict in Sandžak, so far (B92 31.10.2010).

The regional engagement of the EU in Sandžak is very limited. Turkey appears to be a more present actor in conflict resolution in Sandžak. Interestingly, Mufti Zukorlić as one of the main regional actors refers to European standards in the dispute on Serbian districts, for example. The question is whether this is an effect of norm adaption or a distortion of facts in order to exploit the legitimacy of the EU. Here, it will be interesting to see who can successfully use the normative power of the EU for own interests, whether Belgrade or Mufti Zukorlić.

\section{Conclusion}

The EU's promotion of minority protection has been primarily effective in the adoption of a legal framework on minority protection and against its own benchmarks. The regional engagement of the EU is very limited and, its leverage on minority protection in Sandžak relies mainly on a trickle-down effect. In the context of the Stabilization and Association Process, the EU has two instruments at its disposal: political conditionality through the membership incentive and convergence through socialization-based methods. Effectiveness relied here mainly on the credibility and benefits of EU membership exceeding the cost of compliance. Socialization functions less effectively as it is hindered by the vague definition of the minority criterion, and it may be a long-term effect that cannot be evaluated right now. In the concrete case study, Serbia complied formally with EU demands and adopted all relevant international conventions on national minorities. Nevertheless, implementation went slowly. Strong Serb nationalism and a very centralized state structure explain this reluctance as it functions as a counternorm to minority protection. Although there is a majority supporting EU membership (Gallup Balkan Monitor 2009, p. 2), Euroscepticism exists (Renner 2009, p. 453). Moreover, the EU's monitoring has been less continuous over time and lacks consistent benchmarks. The lack of coherence and the indecisiveness of the minority-Copenhagen criterion contribute to difficulties in translating the norm into the domestic context.

Anyhow, the Copenhagen criterion presents a milestone in the protection of minorities and is a useful tool to the EU to settle inter-ethnic and inter-state conflicts before accession. Having this in mind, the EU should enforce more strongly the protection of the Bosniak minority and the improvement of the socio-economic situation in Sandžak. Continuous and targeted monitoring based on clear benchmarks would increase the effectiveness of the EU's promotion of minority protection. Similarly, the EU could deploy more extensively accession conditionality with regard to actually implementing minority protection. This potential may be further used when accession negotiations are opened. Serbia is strategically an important partner in the Western Balkans and more attention should be paid to its internal developments (Petrisch 2009, p. 11-21). The neglect of Sandžak by the Serbian government and the reluctance of the EU to engage in Sandžak's issues, all does not help to solve the regional problems that might cause serious trouble in the future.

\section{Literature}

B 92 (31.10.2010): Mufti wants autonomy, internationalization. Online: http://www.b92.net/eng/news/politics-article.php?yy $y y=2010 \& m m=10 \& d d=31 \& n a v_{-} i d=70618$, [Downloaded on 17.05.2011].

Beichelt, Timm 2010: Externe Demokratieförderung. In: Neue Politische Literatur, $N^{\circ} 3$, p. 447-468.

Bochsler, Daniel (2010): Regional Party Systems in Serbia. In Vera Stojarová, Peter Emerson (Eds.): Party politics in the Western Balkans. London: Routledge (Routledge research in comparative politics, 28), p. 130-150.

Bodiroga-Vukobrat, Nada (ed.) 2009: Die Europäische Union und Südosteuropa: Herausforderungen und Chancen (Schriften zu Mittel- und Osteuropa in der Europäischen Integration $\mathrm{N}^{\circ} 7$ ), Hamburg: Kovac.

Burnell, Peter J. 2010: New challenges to democratization. London: Routledge.

De Witte, Bruno 2002: Politics versus law in the EU's approach to ethnic minorities. In: Zielonka 2002: Europe Unbound (Routledge advances in European politics $\left.\mathrm{N}^{\circ} 7\right)$ London: Routledge, p. 137-160.

Checkel, Jeffrey T. 2001: Why Comply? Social learning and European identity change. In: International Organization 55 (3), p. 553-588.

Committee on the Elimination of Racial Discrimination (2011): Concluding observations on Serbia: UN High Commissioner for Human Rights, 10.03.2011. Online: http://www2.ohchr.org/ english/bodies/cerd/docs/co/Serbia_AUV.pdf, [Downloaded on 18.05.2011]. 
Council of the European Communities 1993: Presidency Conclusions. Copenhagen European Council - 21-22 June 1993. Online: http://www.europarl.europa.eu/enlargement/ec/ pdf/cop_en.pdf [Downloaded on 25.01.2011].

Council of Europe 1995: Framework Convention for the Protection of National Minorities (FCNM). Online: http://www.coe.int/t/ dghl/monitoring/minorities/1_AtGlance/PDF_Text_FCNM_de.pdf [Downloaded on 01.12.2010].

European Commission 2007: Serbia 2007 Progress Report. Commission Staff Working Document. Online: http://ec.europa. eu/enlargement/pdf/key_documents/2007/nov/serbia_progress_ reports_en.pdf [Downloaded on 01.12.2010].

European Commission 2010: Serbia 2010 Progress Report. Commission Staff Working Document. Online: http://ec.europa. eu/enlargement/pdf/key_documents/2010/package/sr_rapport_ 2010_en.pdf [Downloaded on 25.05.2011].

European Union 2010: Charter on Fundamental Rights. In: Official Journal of the European Union. Online: http://eur-lex.europa. eu/LexUriServ/LexUriServ.do?uri=OJ:C:2010:083:0389:0403:EN: PDF [Downloaded on 25.01.2011].

Freedom House 2010: Serbia. In: Freedom House 2010: Nations in Transitions. Democratization from Central Europe to Eurasia. Online: http://www. freedomhouse.org/images/File/nit/ 2010/NIT2010-Serbia-proof-II.pdf [Downloaded on 24.01.2011].

Gallup Balkan Monitor 2009: Perceptions of the EU in the Western Balkans. Online: http://www.balkan-monitor.eu/ files/Gallup_Balkan_Monitor-Focus_On_EU_Perceptions.pdf [Downloaded on 26.05.2011].

Grävingholt, Jörg, Leininger, Julia and Schlumberger, Oliver 2009: Demokratieförderung: Quo vadis? In: Aus Politik und Zeitgeschichte 13, p. 28-33.

Grimm, Sonja 2009: External Democratization After War: Success and Failure. In: Wolfgang Merkel/ Sonja Grimm (eds.): War and Democratization. Legality, Legitimacy and Effectiveness, London/ New York: Routledge, p. 69-93.

Helsinki Committee for Human Rights in Serbia 2010: Annual Report on Human Rights: Serbia in 2009. Europeanization accomplishments and limitations. Online: http://www.helsinki. org.rs/doc/ Report2009.pdf [Downloaded on 24.01.2011].

Hughes, James and Sasse, G. 2003: Monitoring the Monitors: EU Enlargement Conditionality and Minority Protection in the CEECs. In: Journal on Ethnopolitics and Minority Issues in Europe, $\mathrm{N}^{\circ} 1$, p. 1-35.

International Crisis Group 2005: Serbia's Sandžak: Still Forgotten. Europe Report $\mathrm{N}^{\circ}$ 162. Online: http://www.crisisgroup.org/ / media/Files/Europe/162_serbia_s_sandzak_still_forgotten.ashx [Downloaded on 14.01.2011].

Jackson-Preece, Jennifer 1998: National minorities and the European nation-states system, Oxford: Clarendon Press.

Kelley, Judith G., 2004: International Actors on the Domestic Scene: Membership Conditionality and Socialization by International Institutions. In: International Organization, Vol. 58, N³, p. 425-458.
Kubicek, Paul 2003: The European Union and Democratization, New York: Routledge.

Merkel, Wolfgang 2010: Systemtransformation. Eine Einführung in die Theorie und Empirie der Transformationsforschung, Wiesbaden: VS Verlag für Sozialwissenschaften.

Petritsch, Wolfgang 2009: Serbia matters: domestic reforms and European integration (Southeast European integration perspectives $\mathrm{N}^{\circ} 1$ ), Baden-Baden: Nomos-Verl.-Ges.

Renner Stephen and Florian Trauner 2009: Creeping EU Membership in South-East Europe: The Dynamics of EU Rule transfer to the Western Balkans. In: European Integration, Vol. 31, N 4, p. 449-465.

Riegler, Henriette 2000: Transformation processes in the Yugoslav successor states between marginalization and European integration (Wiener Schriften zur Internationalen Politik $N^{\circ} 2$ ), Baden-Baden: Nomos-Verl.-Ges.

Sandžak Committee for Protection of Human Rights and Freedoms (2006a): General situation Sandžak. Sandžak Committee for Protection of Human Rights and Freedoms. Online: http:// www.san-odbor.org/Dokumenta/Izvestaji\%20i\%20analize/ [Downloaded on 18.05.2011].

Sasse, Gwendolyn 2008: The politics of EU conditionality: the norm of minority protection during and beyond EU accession. In: Journal of European Public Policy, Vol. 15, Nº, p. 842860 .

Schimmelfennig, Frank 2008: EU political accession conditionality after the 2004 enlargement: consistency and effectiveness. In: Journal of European Public Policy 15 (6), p. 918-937.

Skovgaard, Jakob 2009: Towards 'Consociationalism Light'? The EU's, the Council of Europe's and the High Commissioner on National Minorities' policies regarding the Hungarian Minorities in Romania and Slovakia. In: Journal on Ethnopolitics and Minority Issues in Europe, Vol. 8, № 2, p. 1-22.

Szöke, Nóra 2010: Erfolg und Scheitern schwieriger Transformationsprozesse auf dem Balkan: ein Vergleich der Demokratisierungsprozesse in Kroatien und Serbien. Berlin: Humboldt-Universität Dissertationsschrift.

Tarrow, Sidney 1998: Power in movement: social movements and contentious politics. In: Cambridge Studies in Comparative Politics. Cambridge: Cambridge University Press.

UN Special Rapporteur on freedom of religion or belief (2009): Report on Serbia for the UN High Commissioner for Human Rights. Online: http://www2.ohchr.org/english/issues/religion/docs/ A-HRC-13-40-Add3.pdf [Downloaded on 17.05.2011].

Vachudova, Milada Anna 2005: Europe Undivided. Democracy, Leverage, and Integration since 1989. Oxford: Oxford UP.

Wichmann, Nina 2007: Democratization without societal participation? The European Union as an external actor in the democratization processes of Serbia and Croatia (Studien zur Geschichte, Kultur und Gesellschaft Südosteuropas Nº 5), Berlin: LIT Verlag. 